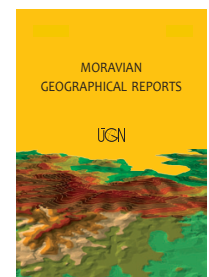

MORAVIAN GEOGRAPHICAL REPORTS

\title{
Rhythm of urban retail landscapes: Shopping hours and the urban chronotopes
}

\author{
Ondřej MULÍČEK ${ }^{\text {* }}$, Robert OSMAN $^{\mathrm{a}}$
}

\begin{abstract}
Daily rhythmical patterns in the city are investigated in depth in this paper. The city is conceptualised here as a cyclical process and described by a sequence of relatively stable spatial-temporal stages. The concept of a chronotope is incorporated in the analysis of retail opening hours in the middle-sized city of Brno (Czech Republic), in order to identify distinct fusions of specific times and specific retail places and to examine their position within the daily rhythms of the city. There are distinct time-space retail configurations (chronotopes), which play crucial roles in the social negotiation and imagination of basic temporal categories, such as early morning, late morning, lunchtime, afternoon, evening, as being taken-for-granted in the urban context. More generally, the paper offers an example of the ways in which the specific daily rhythms of the city are produced and structured.
\end{abstract}

Keywords: retail, urban rhythm, urban time, chronotope, opening hours, Brno, Czech Republic

Article history: Received 10 May 2017; Accepted 10 November 2017; Published 31 March 2018

\section{Introduction: retailing in the post-industrial city}

The rise of the modern industrial city engendered qualitatively new social relations and patterns accompanying industrialisation processes when compared with the pre-industrial era (Saunders, 1985). For a long time, the issues reflected in urban research were focused predominantly on the production aspects of urban industrialism - urban production functions were taken as key agents of urban development and internal urban differentiation. Indeed, it is not surprising as productive industrialism as a mode of urban labour reproduction and capital accumulation became deeply rooted into daily urban routines, in the social stratification of the urban population and in place-making in city space (Byrne, 2002). It was Castells' theory of collective consumption that drove research foci to the city itself. According to Castells (1977), exclusively urban issues do not arise from the productive role of cities but from their exclusiveness within consumption processes. Cities are places where the state is systematically engaged in the reproduction of labour through the supply of collectively consumed goods and services. Therefore the elementary urban processes are no more purely industrial: urbanity and city-being relates increasingly to the various processes of collective and individual consumption. Likewise, Baudrillard (1973) contends that while the industrial system socialised the masses as labour power, further societal development promotes their consumption power.

Consumption activities produce and remodel urban structures in different ways compared to industrialisation processes. The emergence of new types of goods with different geographical distributions within the urban space, the conflict of new commodities and ways of their consumption with the traditional local milieu, the production of new spaces of consumption replacing the former dominant spaces of production, as well as new emerging forms of social stratification based on cultural factors and consumption patterns - these are some examples of the various ways in which consumption patterns interplay with the physical, social or functional urban structures (Herrschel, 1999; Crewe, 2000). Rather than industrial production, consumption activities bring new post-industrial focal points like shopping malls, hypermarkets and leisure parks (Jayne, 2006), transforming the meanings, times and rhythms of the old urban places and attaching new functions and symbolism to them.

Urban consumption represents a complex tissue of overlying consumer spaces and rhythms. While the industrial city has been frequently depicted as a well-

\footnotetext{
a Department of Geography, Faculty of Science, Masaryk University, Brno, Czech Republic (*corresponding author: O. Mulíček, e-mail: mulicek@geogr.muni.cz)
} 
synchronised time machine or isorhythmia (Lefebvre and Elden, 2004), the urban post-industrial period has been seen as desynchronised, destandardised or polyrhythmic in temporal terms (Paolucci, 2001; Stavrides, 2013; Mulíček, Osman and Seidenglanz, 2016). Urban commerce becomes a more and more influential agent of urban everydayness and leaves deep imprints in the spatiotemporal organisation of the city (Kärrholm, 2009, 2012).

This article aims to conceptualise the city as a cyclical repetitive process through chronotopic analyses of retail opening hours. In spite the fact that retail represents just one part of the broad set of urban consumption activities, we argue that it contributes significantly to the overall rhythmicity of the city. While the spatial anchoring of urban retailing and shopping is given by the physical location of particular retail units differing in terms of retail floor area and the assortment of goods, the category of retail temporality includes the opening hours of shops. Employing the extensive datasets on the retail network in the Czech middle-sized city of Brno, we conceptualise particular stores as specific urban places, which can be grasped through their spatial as well as their temporal dimensions. We introduce the concept of chronotope in order to identify distinct fusions of specific times and specific retail places and to examine their position within the daily rhythm of the city. In this sense, we argue that open shops occupying specific urban places and times are very significant institutional agents defining and delimiting particular stages within the course of the day in the city. The message of the article thus consists in the description the distinct time-space retail configurations (chronotopes), which play a crucial role in the social negotiation and imagination of basic temporal categories, such as early morning, late morning, lunch time, afternoon and evening, as being taken-for-granted in the urban context (Jauhiainen and Mönkkönen, 2005; Jauhiainen, 2007). At the theoretical level, the paper aims to find and differentiate the ways of describing the time-space of the city or, more specifically, to diversify the spatiotemporal description of the city. This theoretical ambition is formulated by the following research questions: "How does one describe the temporal heterogeneity of the city?"; and "How does one describe the city in spatiotemporal terms?".

\section{Theoretical background}

\subsection{Retail strategies}

According to de Certeau (1984, p. 38) the strategies are "actions which, thanks to the establishment of a place of power, elaborate theoretical places (systems and totalising discourses) capable of articulating an ensemble of physical places in which forces are distributed", while 'tactics' is seen as "procedures that gain validity in relation to the pertinence they lend to time - to the circumstances which the precise instant of an intervention transforms into a favourable situation". He considers strategies, to certain extent, as the spatialised settings for time-space tactics. The location of retail premises within an urban territory, their opening hours throughout the day, week and year, can be thus viewed as the rational power places of commercial strategies - fixed however not only in space, but also in time.

A considerable body of literature has been devoted to the purely spatial aspects of retail location strategies. Spatialised strategies still represent a well-established research field, however, somewhat fading within the discourse of the socalled reconstructed retail geography (Crewe, 2000). On the other hand, the temporal aspects of retailing seem to get increasing attention from researchers, as well as from political viewpoints.

Time policies (or policies of time) are gradually being introduced, principally in the European countries. Their core concepts are relatively diverse, however, as they come from different contexts (most often represented by urban planners, architects, sociologists, geographers and economists) and as they reflect some specific time-cultures of particular countries. In the UK, time policy is understood as part of a wider concept of geopolitics (Klinke, 2013), while in Italy it is seen as a tool for setting equal opportunities for different population groups (an emphasis is placed mainly on gender equality: Bonfiglioli, 1997; Mareggi, 2002; Pasqui, 2016). In Germany, time policies are used to coordinate and synchronise various services and functions of the state (Boulin and Mückenberger, 2005; Mückenberger 2011), whilst in Portugal they are primarily tools for planning and regulating mobility and accessibility (Fernandes, 2011; Fernandes and Chamusca, 2014; Fernandes et al., 2015). The French approach covers the issues of spatiotemporal planning and so-called "chrono-urbanisme", in an effort to respond to the social inequalities associated with the overall acceleration of society, with the irregularity of everyday activities, uncertainty, an unpredictable and difficult-to-plan future, as well as with time-stress (Ascher, 1997, 2001, 2008; Gwiazdzinski, 2014, 2015; Straw, 2015).

In the Czech Republic, as well as in the post-socialist countries of Europe, these policies are not yet developed at the official level. What is, however, typical and therefore unifying all these different concepts of time policies, is a participatory bottom-up principle: the specific contents of these time policies are derived from the particular needs of the community (Bonfiglioli, 1997; Goodin, 2010; Mückenberger, 2011). In this respect, there is a growing pluralism between different concepts of time. There are two concepts of time commonly used in the current practice of European time policies, namely urban time (linear, mechanical), and social time (heterogeneous and discontinuous) (Melucci, 1996; Hoffmann and Lapeyre, 1995; Hoffmann, 1997; Bonfiglioli, 1997; Mareggi, 2002; Stavrides, 2012, 2013; Pasqui, 2016). Social time is primarily understood as the behaviour of an urban society, including socially established rituals, habits, traditions and holidays. It can be perceived as a kind of timing of routinely repeated social activities such as daily getting up, eating, working, training, sports and relaxation (Adam, 1994, 1995, 2004). On the other hand, urban time is represented by the timing of urban services and institutions. We can consider the opening and closing times of various institutions, offices, schools, hospitals and, of course, shops, as classic representatives of urban time (Kärrholm, 2009, 2012; Fernandes and Chamusca, 2014).

The retail times and rhythms became important subjects of discussions, negotiations and regulations, which only reflect the changing societal and economic meanings of time, the loosening synchrony of modern industrial towns and the rising flexibility of post-industrialism. In this respect, Paolucci (2001) draws attention to the politics of time as attempts to grasp the power of time in the fragmented space of the post-industrial city. These politics can take a number of forms - they include global discussions on the effects of daylight saving time, local timetable planning activities in mostly Italian towns (Bonfiglioli, 1997; Mareggi, 2002), negotiations on time regimes in night-economy urban areas, 
as well as shopping hours regulation issues (Wenzel, 2011). It is particularly the deregulation and extension of shopping hours in the course of the day and week, which since the 1990s is a vital issue raised not only in political debates but also reflected in academic research. This issue was seized mainly by economists and thus somewhat narrowed down to studying the relationship between the hours of retail operation and consumer demand and the diversified impacts of deregulation on the competitiveness of retail premises (Wenzel, 2011; Inderst and Irmen, 2005; Lanoie, Tanguay and Vallée, 1994). The studies revealed in general "a strategic uncertainty between decision-makers in the retail sector" (Kosfeld, 2002, p. 52), concerning the temporal coordinates of their businesses. Temporal strategies cope with a plethora of changing work schedules, family responsibilities and the schedule-independent shopping tactics of consumers (Kaufman and Lane, 1994), and deregulated retail timespace thus hardly shows any clear patterns.

Kärrholm (2009) identifies two groups of processes through which retail activities shape the urban timespace - synchronisation and territorialisation: they can be called strategic in de Certeau's approach. There are several more or less clearly pronounced synchronisation strategies described in his case study of the city of Malmö, including synchronisation to the rhythms of other commercial subjects, to peoples and collectives. Kärrholm points out that purely temporal synchronisation processes go inevitably hand in hand with spatial localisation and synchorisation. Retailing introduces specific rhythms and synchronicities into specific territories, imposing a kind of spatio-temporal order on them. From this point of view and in accordance with Kärrholm, this study will not be interested in retail customers' tactics, i.e. in the social demand time of the shoppers. On the contrary, the subject interest here lies in the analysis of the strategies of retailers that are represented by the offer urban time of retail.

\subsection{Chronotopic approach to retail rhythms}

Urban everydayness consists of numerous repetitive actions, situations and movements which fuse together to orchestrate overall city rhythmicity - a relatively stable syntax of places and times whose reproduction is driven by various schedules and timetables. Lefebvre treats rhythms as measures sui generis, specific analytical standpoints capable of structuring the urban environment in terms of its time-spatial unity, manifestations of (de) synchronised and (de)synchorised routines (Lefebvre and Elden, 2004). Lefebvre and Elden, however, do not offer particular analytical and interpretative tools enabling an operationalisation of rhythmanalysis. Some authors, such as Folch-Serra (1990), Holloway and Kneale (2000) or Crang (2001), draw attention to the concept of chronotope developed by Russian philosopher and literary critic Mikhail Bakhtin. The chronotopic approach emphasises the dialogue between specific times and specific spatial settings. A chronotope can be understood as an analytical unit materialising (spatialising) time and, at the same time, timing space. Neither time nor space are privileged categories here - both of them are inseparable and mutually interwoven constituents of specific time-space (Bakhtin, 1980, 1984, 1986, 2002). Bakhtin himself employed the chronotope concept to outline a typology of situations in novels, pointing out its representational importance (FolchSerra, 1990). From a geographical point of view, a chronotope is defined by rhythmic presence, co-presence and absence of people, objects, noises and smells taking place in a concrete place and concrete time (Crang, 2001, 2005). Seen from a research perspective, it is the analytical frame organising the viewpoint, scope and scale of the enquiry.

A chronotope represents a "distinctive bundle of time and space” (Harvey, in Folch-Serra, 1990, p. 264) grasped through narration, which interlinks present people, processes and activities into a single, interpretatively convenient timespace unit. Binding the units together, we can narrate the spatially differentiated temporality of the city, its rhythmicity and tempo. In our case study, the chronotope concept is implemented within the specific segment of retail time-space. The dialogical nature of the retail chronotope(s) stems from multi-layered and multi-scalar linkages between the spatial and temporal dimensions of the retail strategies taking place within specific urban context(s). Lefebvre's well-known notion of rhythm as the interaction between place and time can be invoked here, highlighting the crucial role of rhythms in the appropriation and negotiation of urban time-space (Lefebvre and Elden, 2004).

\section{Methodology}

The empirical goal of this paper is to conceptualise a city as a cyclical repetitive process through the chronotopic analysis of retail opening hours. In other words, we aim to use the strategic location of retail facilities in space and time in order to conceptualise the city as a kind of a cyclical loop. The theoretical goal of the paper is closely linked to this empirical framing. It consists in a search for the differentiated ways of capturing the time-space of the city, especially with respect to the diversified spatiotemporal description of the city. The spatiotemporal description can be approached from a variety of perspectives. Firstly, the city can be structured into particular spatial areas with relatively homogeneous temporalities (time regions). The basic organisational principle of the analytical description is therefore spatial, exploring the city as a spatial mosaic, from one region to another (Mulíček, Osman and Seidenglanz, 2015). Secondly, the temporal view can be employed primarily in the sense that it produces a description of the city for particular time periods. Such a city description follows the logic of temporal ordering, approaching the city as a succession of different times coming one after another (Mulíček, Osman and Seidenglanz, 2016). These two perspectives, however, can be combined in many different ways (Mulíček and Osman, 2017).

This paper draws on the latter second perspective on spatio-temporal urban depiction as it puts the accent on temporal structuration. In this respect, the concept of chronotope is employed as a specific kind of time-space. Particular chronotopes are arranged and described in a time order which follows the daily cycle. The underlying motivation is to show the city as a dynamic process consisting of repeating rhythms, unstable and fluid in its essence. Considering the city as a loop of cyclically alternating time-spaces is, to a certain extent, a critical response to those imaginaries that represents city as static and timeless entity.

This approach also implies the design of the research, which has the character of a case study carried out in a single city. The purpose of the case study is certainly not to provide a generic description of city time-space. It is rather a case that allows the researchers to illustrate a certain conceptualisation of the city and the related types of its spatiotemporal description. Therefore, the choice of the city is not based on pre-defined criteria, but 
is mainly driven by pragmatic motivations. The empirical part of the research was conducted in the city of Brno, the second largest city in the Czech Republic, with approximately 400,000 inhabitants and the destination of more than 100,000 daily commuters. Since the 1990 s, the city has experienced a thorough deep transition from a socialist industrial production centre to a more diversified urban economy. The transitional period was marked not only by intensive de-industrialisation but also by the massive growth of retail and other consumer services,

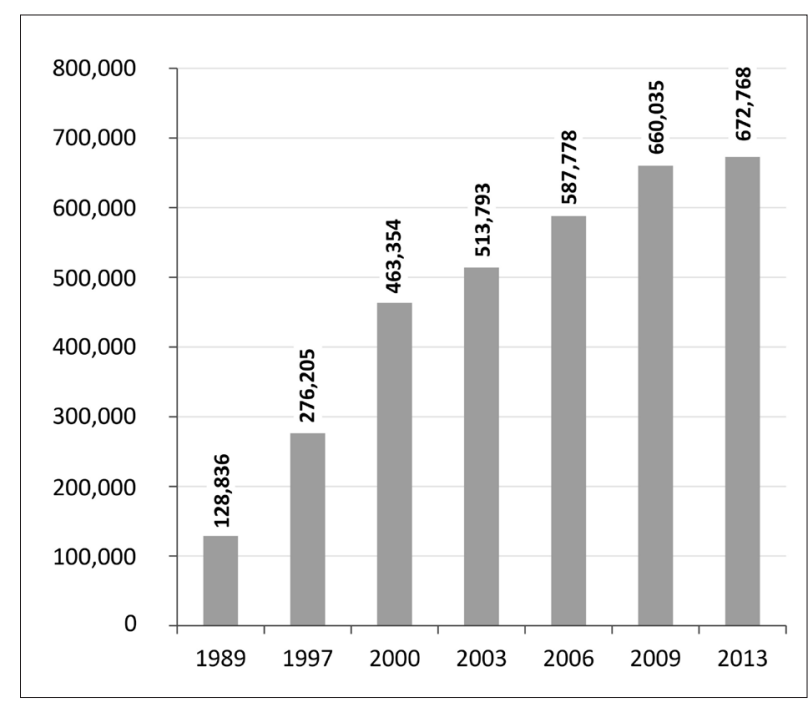

Fig. 1: The growth of total retail floor space in Brno 1989-2013 ( $\left.\mathrm{m}^{2}\right)$. Source: Mulíček and Osman, 2013 which were strongly marginalised during the socialist central-command economy. The socialist retail 'shortage' was compensated for after 1989, as the total retail floor space increased more than five-fold between 1989 and 2013 (Fig. 1) (Mulíček and Osman, 2013).

The decision to use data on the location of retail units to describe Brno's time-space was similarly pragmatic. In the case of the availability of similar data, it would also be possible to use, for example, data on the location and opening times of services, restaurants, withdrawals from ATMs, etc. The choice of the empirical database was motivated by its very existence, its public availability and the spatiotemporal character of the data. The city of Brno keeps the line of comprehensive municipal retail surveys taken quasi-regularly in 1997, 2000, 2003, 2006, 2009 and 2013. The surveys focus only on 'bricks-and-mortar' shops: mobile vendors' stands, e-shops, as well as pubs, bars and restaurants are not covered. We employ here the latest retail database from the year 2013 (Mulíček and Osman, 2013), including information on 3,587 shops in the city (Fig. 2). Each store is described not only by its retail floor space, but also by location, assortment and opening hours on weekdays, and (if open) on Saturday and Sunday. The dataset represents a useful analytical base for the identification and description of daily or weekly retail rhythms: it enables the researcher to link specific urban retail places with specific times in order to operationalise the chronotope concept.

The data analysis employed here follows the temporal regionalisation of the time-space of the city. In other words, the analysis inspired by Bakhtin's chronotope concept,

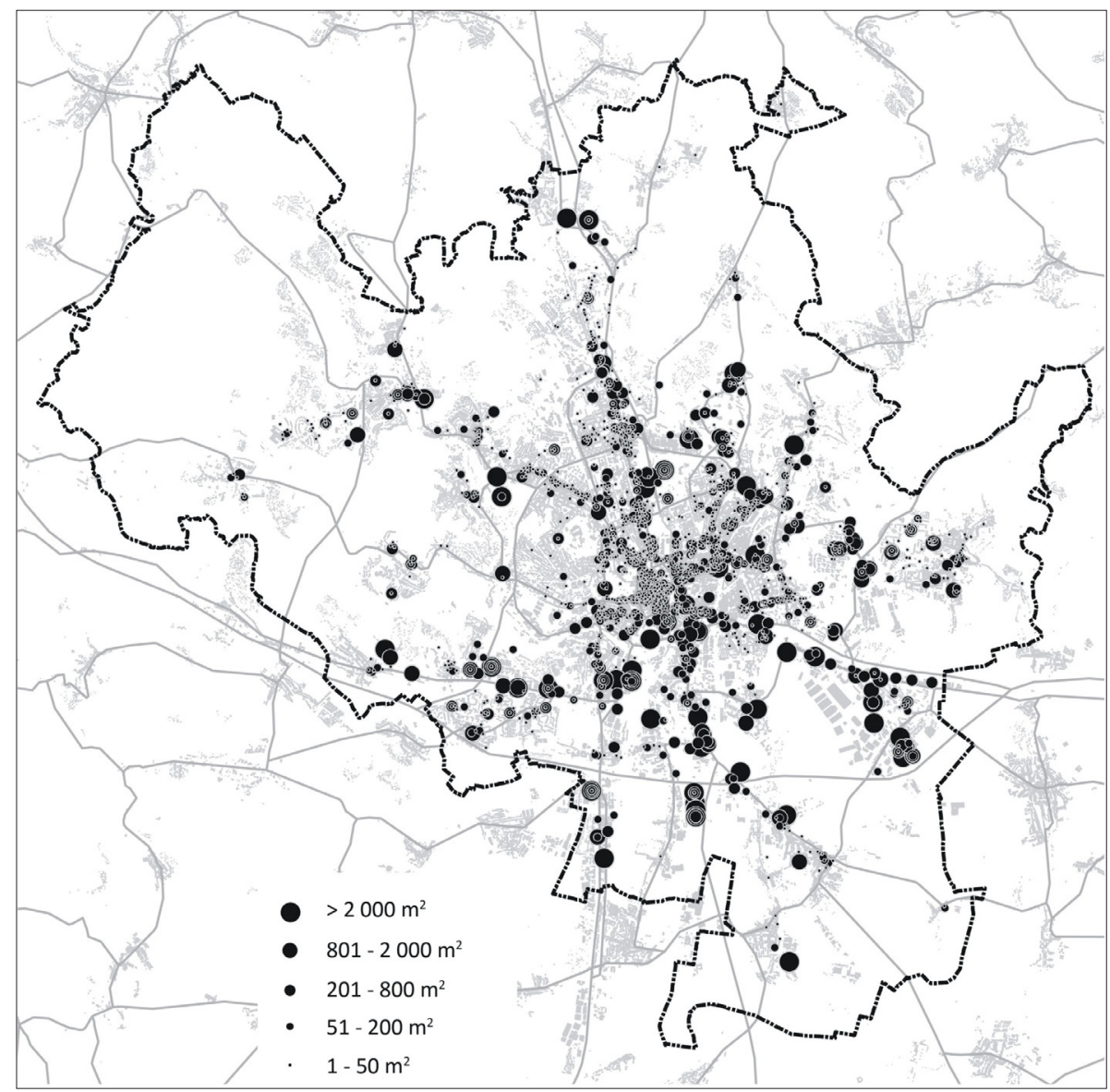

Fig. 2: The spatial structure of retail in Brno 2013 (store sales area, $\mathrm{m}^{2}$ )

Source: Mulíček and Osman, 2013 
focuses on identifying changes in the behaviour of retail units over time. The first step in this chronotopic analysis was to investigate the basic distribution of the proportion of shops open during the working day (Fig. 3). Four distinct phases of a business day, based on the number of open retail units, were identified using this histogram: the first of these was the phase between 23 and 05 hours, which we call the night chronotope; the second is the phase between 5 a.m. and 9 a.m., labelled the morning chronotope; the third between 9 a.m. and 6 p.m. is called the day chronotope; and the fourth between 18 and 23 hours, is called the evening chronotope. In the second step of the analysis, four specific space time-spaces of Brno were identified (see Fig. 3 below). In the third step, the spatial dimension was added to each of the chronotopes defined - the shops opened in the relevant period were visualised on the map according to their specific location (Figs. 4-7 below). In the fourth and last step of the analysis, these chronotopes were individually described in the order in which they follow one another during the course of the day (Fig. 8 below).

\section{Results and discussion}

\subsection{Weekday retail rhythm}

The opening and closing of shops within the course of the day represent rhythms that aggregate various synchronisation strategies, reflecting not only the size, assortment profile and spatial location of particular shops but also other contextual temporalities produced by the numerous types of pacemakers. Figure 3 shows the weekday retail rhythm in Brno visualising the changing shares of open shops during the 24 hours of the day. An examination of the graph indicates the concentration of opening hours to the part of the day between 8-9 a.m. and 6-7 p.m. The beginning of the average opening hours on weekdays is at 8:39 and the end at 18:22. Stores operated during the late evening, night and early morning hours represent only a small segment of retail premises in the city. Leaving aside the clear and rather expected difference between light and dark hours, we can trace out other subtle temporal borders which separate specific and transient retail configurations. For example, the retail map of the early morning shows a distinct spatial and assortment pattern of shops compared to the retail structure in the middle or end of the day. The weekday urban retailing can be thus conceptualised as a sequence of short-term transitive configurations of retail, interwoven with other urban rhythms.

\subsection{Night chronotope}

A number of research reports concern night city economies: many of them are spatially targeted to specific parts of the city - the city centres or inner city zones. Night-time rhythms have been analysed in Groningen, Utrecht and Rotterdam (Schwanen, van Aalst, Brands and Timan, 2012), as well as the evening and night-time city centre activities in Swansea (Bromley, Tallon and Thomas, 2003) or the nocturnal life of Paris (Mallet, 2014). These studies mostly confirm the important role of retailing in the spatio-temporality of the urban night (together with night clubs, restaurants, pubs and bars, stops of night public transport, etc.). At the same time they also point out that night economies often clash with various forms of institutionalised time regulations, "police hours" or curfews.

As mentioned above, night-time businesses represent only a small part of the total retailing activity in Brno, in spite of the fact that there are no legal directives regulating night opening hours in the Czech Republic. From our data base, there are 14 stores operating non-stop, 3 stores open until midnight and 16 shops closing at 11 p.m. Two Tesco hypermarkets are the biggest shops with continuous opening hours in the city, with retail floor space more than about 10,000 square metres each, while the rest of the non-stop retailing involves very small stores not exceeding 80 square meters (one pharmacy, 5 groceries and 6 tobacconists, usually with extended offer of alcoholic beverages). There is, however, no universally valid narrative standing behind the temporal strategies of those non-stops.

When analysing the case of pharmacy, we can see the combination of spatial and institutional factors. The shop is the only pharmacy in the city where one can buy medicaments in the period of the night-time from 10 p.m. until 7 a.m. This night service is partially contracted by the city authorities as the pharmacy is situated in close proximity to all-night medical and dentist emergency rooms. The pharmacy represents, then, part of the semi-institutionalised and localised system of night health care. The specific spatiality gives birth to a specific temporality of the store in shaping its privileged and central position in the chronotope of night medical help. This

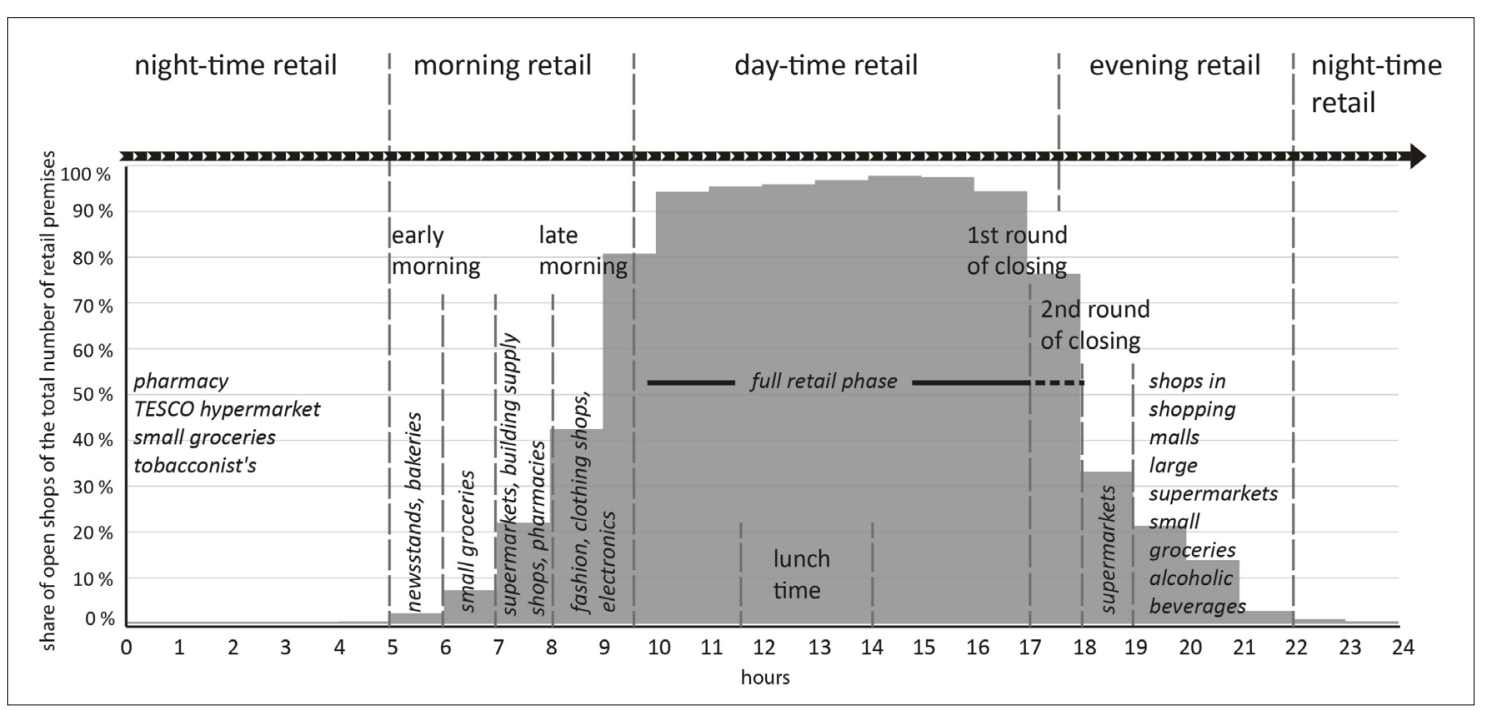

Fig. 3: The share of open shops of the total number of retail premises and the daily rhythm of retail configurations: Brno 2013, weekday. Source: Mulíček and Osman, 2013; authors' analysis 
position is, however, rather transient - the store becomes just an ordinary item in the other 125 pharmacies in the city during the daytime.

The temporality of small non-stop groceries and tobacconists stems from adaptation to the local context. They mostly fall within the category of convenience stores targetting a specific group of night customers - usually people on their way home (from pubs and bars, from late night shifts, from the central train or bus station) or people working in the streets of the night city (taxi drivers, policemen and emergency ambulance staff, etc.). Some of these stores are located in central locations, some of them not, but we have to be aware that the term 'central location', borrowed from the geography of the daytime city, obtains different meanings on the nocturnal map. The night distorts the traditional city structure and 'centrality' gravitates towards a few animated and living places. All small non-stop stores under examination form the central locations sui generis, regardless their absolute geographical position. They are the night micro-clusters of people and activities, the foci of night spatial order, which fades away as the morning brings new focal points and centralities.

The Tesco non-stop hypermarkets can be examined as a third distinct typological case of night retail. Their timepolicy in Brno reflects much more the Tesco global/national corporate strategy, not simply local factors. Tesco, which entered the Czech Republic in 1996, adopted the extra-long opening hours in order to strengthen its position within the highly competitive national retail market. Starting in 2005, Tesco introduced non-stop operations within the network of its hypermarkets in large and middle-sized Czech cities. This policy of 24/7 retailing was not followed by other important chain retailers in the Czech Republic, and Tesco employed it as a powerful marketing tool to demonstrate its responsiveness to the (temporal) needs of customers. The high economic costs of night retailing forced Tesco to revise the policy at the end of 2015. Only six hypermarkets (mainly in Prague and Brno) continue with the $24 / 7$ service, while the other 19 stores cut their opening hours in accordance with the effective demand of customers. Tesco non-stop stores in Brno can thus be perceived as indicators of the day-and-night living urban economy which cannot be found in smaller Czech cities and towns. The "colonisation of the night" (see Melbin, 1978) by Tesco is not, however, just a pragmatic economic strategy of retail synchronisation with the schedules of time-poor people: it embraces an important neoliberal symbolism, presenting Tesco as the modern retailer which breaks the spatiotemporal borders of traditional retail niches.

The retail times and places contribute significantly to the building of the night-time Brno chronotope. Nonstop retailing privileges a limited number of urban places, producing a specific night geography of the city. The few non-stop shops represent hotspots, regardless of their size or location, just because they are few in number. The different groups of customers are spatially joined, as the temporality meaningfully defines spatiality within the spatiotemporal order of the night.

\subsection{Morning chronotope}

The frontier between night and day in the city is never clear, more likely it takes the form of a kind of buffer zone. Looking at Figure 3, we can make the wide night-day retail divide approximately between 5:00 and 9:30 a.m. While a little over $2 \%$ of shops open before six o'clock, the share of open stores growths steeply in the next three and half hours and after 9.30 a.m. more than $80 \%$ of shops in the city are open.

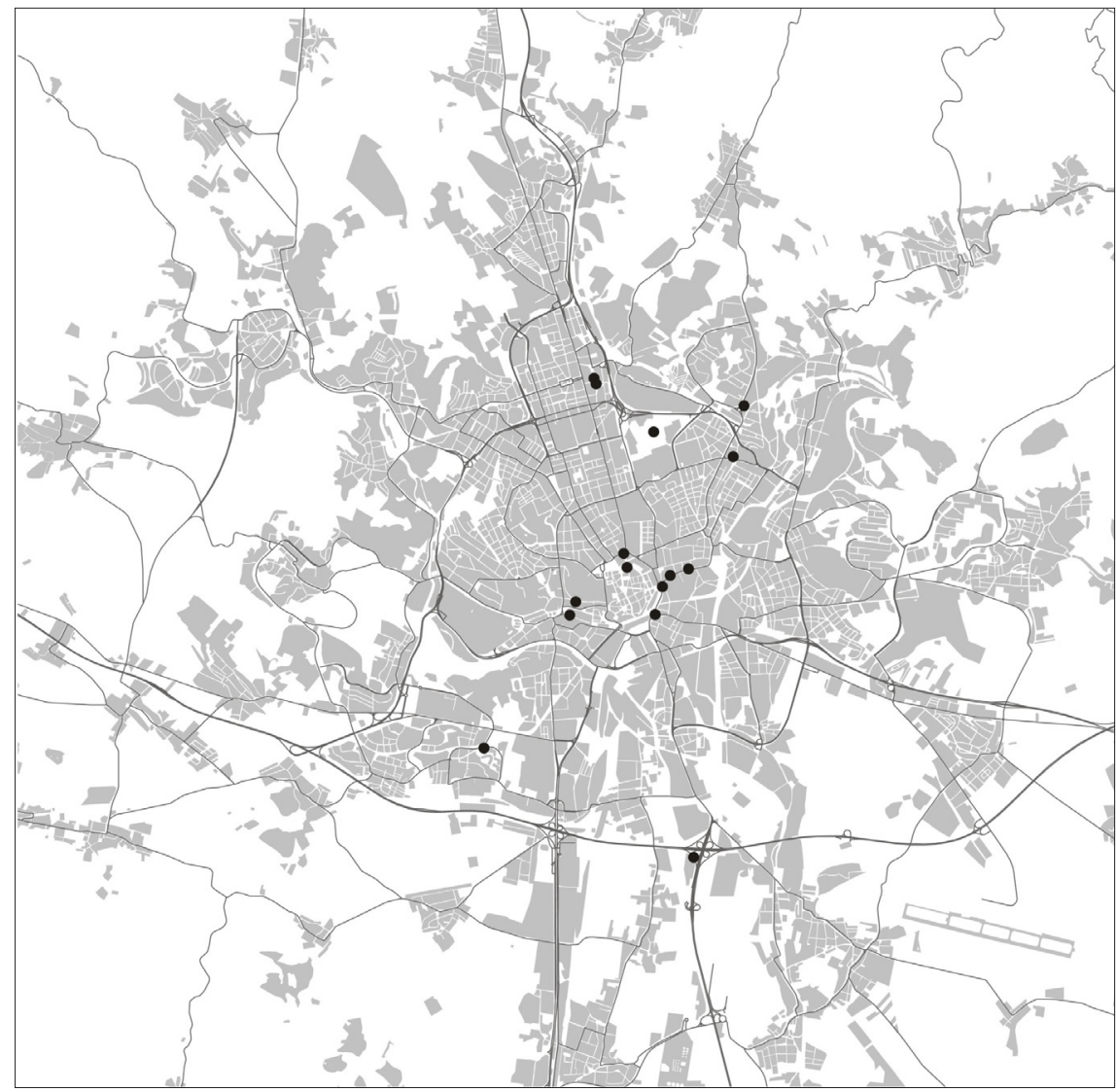

Fig. 4: Night chronotope of Brno in 2013 (1:00-1:59)

Source: authors' analysis 
This everyday rhythm of the morning retail awakening has its internal and quite rigid spatiotemporal structure. The times before 6 a.m. are occupied by a group of shops rather homogeneous in term of assortment and size structure newsstands and tobacconists represent about two-thirds of the 65 shops open before 6 a.m., while the remaining one-third involves only small groceries and bakeries. All these early morning stores show a common feature which lies in their definitional quality, a daily repeated tie to the coming of a new day. Their principal goods, like newspapers, fresh bread and rolls, symbolise circadian rhythm and the stores are the places where this rhythm is materialised and amplified. The early morning shops are to be found mainly at the public transit hubs, fusing with the rhythms of early work-commuters, most typically industrial workers, medical staff and any other employees starting their work ahead of commonly-accepted hours.

Another 180 stores open between 6 and 7 a.m. This round of openings is clearly dominated by grocery stores, still small in size. The assortment structure, however, becomes more diversified. There is an increasing number of stores which provide materials and equipment to self-employed tradesmen or small businesses (plumbers, electricians, bricklayers, etc.). We can find also several green-groceries opening. It has to be pointed out that the early morning retail is not corporate in its nature. Most of the grocery shops working before 7 a.m. are not part of retail chains: their temporalities refer more to autonomous local strategies than to rather uniform top-down time policies.

In the period between 7 and 8 a.m. here is a further structural diversity of retailing, both in terms of assortment and size. The map of grocery stores demonstrates higher densities: not all opening premises fall under the small-sized shops category, as seven o'clock is the usual starting time also for middlesized and large grocery shops and supermarkets. Many of the latter belong to the wider retail chains, applying nationwide opening times strategies. The changes in the structure of to-date opened shops go hand-in-hand with the increasing number of potential customers. The people on their way to school or to work are no more the sporadic representatives of marginal temporalities, they represent the accepted temporal norm. At this time of the day, the 'normal' working day starts and retail temporality fuses closer to the mainstream rhythm of the city. For example, there are many pharmacies opening, as well as building supplies stores, drugstores and car components shops. These stores follow a similar logic in that they are tightly linked to the pragmatic daily activities of their customers or interlinked businesses. A good example is the opening hours of pharmacies, which closely resonate with the typical morning-oriented working time of most of healthcare facilities - medical centres and clinics, as well as small doctor's offices. Late morning retail seems to be much more a pragmatic reflection of the other urban rhythms than an active pacemaker, which to some degree is contrasted to the role of night or early morning retailing.

After 8 a.m. the number of open shops rises steeply and by about 9.30 a.m. approximately $80 \%$ of all retail premises in the city are open. The spatial pattern of city retail is nearly completed and the assortment range reaches its maximal width. This is the stage when the 'leisure shopping' assortment (fashion, clothing stores, electronics, etc.) appears for the first time, and moves the relation between retail place and retail time further. While the unique temporality of night and early morning shops has a definitional meaning for them, the shops opened later on in the morning lose inherently their temporal exclusivity and their spatiality obtains the overriding significance.

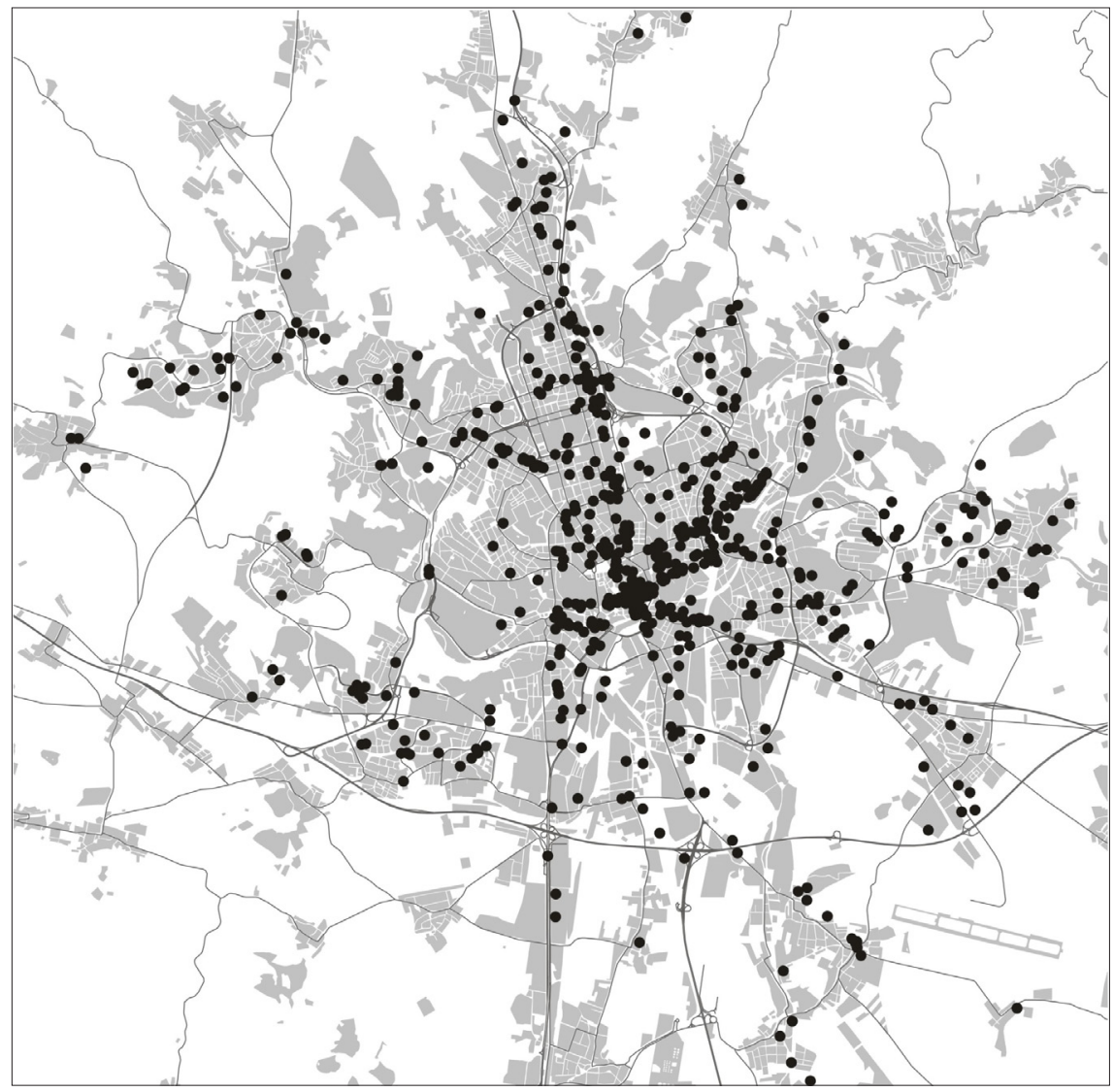

Fig. 5: Morning chronotope of Brno in 2013 (7:00-7:59)

Source: authors' analysis 
IKEA, the home furnishings retail chain, moved the opening hour for all its Czech stores from 10 to 9 a.m. in the autumn of 2013. The motive of the change was to place better the store into its temporal, as well as spatial context:

"...new opening hours better correspond with the needs of our customers, we can satisfy their expectations. Especially families with children like morning shopping. Long-term surveys show that people launch their shopping trips in the morning and they do not use the last hour of our shopping hours as much. Most of the shopping centres in the vicinity open also at 9 o'clock so we believe that the change will be accepted positively..." (IKEA, 2013).

This example from the IKEA store shows the great volatility of morning synchronisation factors and, at the same time, their vitality in economic and marketing terms.

\subsection{Day chronotope}

The phase in which almost all shops are open starts after 10 a.m. in Brno. More than 90\% of the total number of stores are working and this full retail period lasts till 5 p.m. The data describing these particular seven hours of city retailing represent a referential configuration without any distinct temporal, spatial or structural markers - a kind of normative mirror level in which more specific chronotopic patterns of other parts of the day can be reflected. The particular time coordinates of opening hours cannot be linked to specific shops in specific places in this stage. The binary information of 'open/closed' loses some of its interpretive power as the chronotope of the (10-17) city stems from the totality of city shops, nearly all of them open and working.

The period from 10 to 17 o'clock appears to be quite monolithic when seen through the optic of retail activity.
A question arises as to what extent this segment of retail rhythmicity entrains with other rhythms of daily urban life. There are several pace-making moments within the 10-to-17 timeframe, among which the 'lunch-break' is prominent as it belongs to the most common temporal fixes structuring that respective part of the working day in the city. The lunchtime usually means a pause in work, the interruption of flowing working time. Examining the graph in Figure 3, however, there is no visible imprint of lunchtime in the retail opening hours dataset. We can find out that only about $10 \%$ of all shops stay closed for a more or less short lunchtime break. These are mainly very small retail premises (up to $50 \mathrm{~m}^{2}$ retail floor) spread across all assortment categories: the pause usually takes place between 11:30 and 14:00; its average duration is 1 hour; the pause from 12 till 13 is the most typical case. The prevailing absence of a lunch-time break indicates that retail schedules are not a mere mechanical reflection of broadly synchronised individual temporal strategies. They are, instead, the outcomes of an interplay between customer needs, the operative economy of the shop and its synchronisation strategies.

\subsection{Evening chronotope}

The 'full retail' part of the working day ends at 5 p.m., when the first massive round of shop closures starts and the share of open shops falls to $76 \%$. It seems that the "rule": 'first open, first closed' cannot be applied in this case, as the majority of shops closing at 17 o'clock show an average or even late opening times. As this set of shops includes mainly small- or middle- sized retail businesses in noncentral localities, we can hypothesize that their opening hours follow closely the typical 8 or 9 -hour working shift

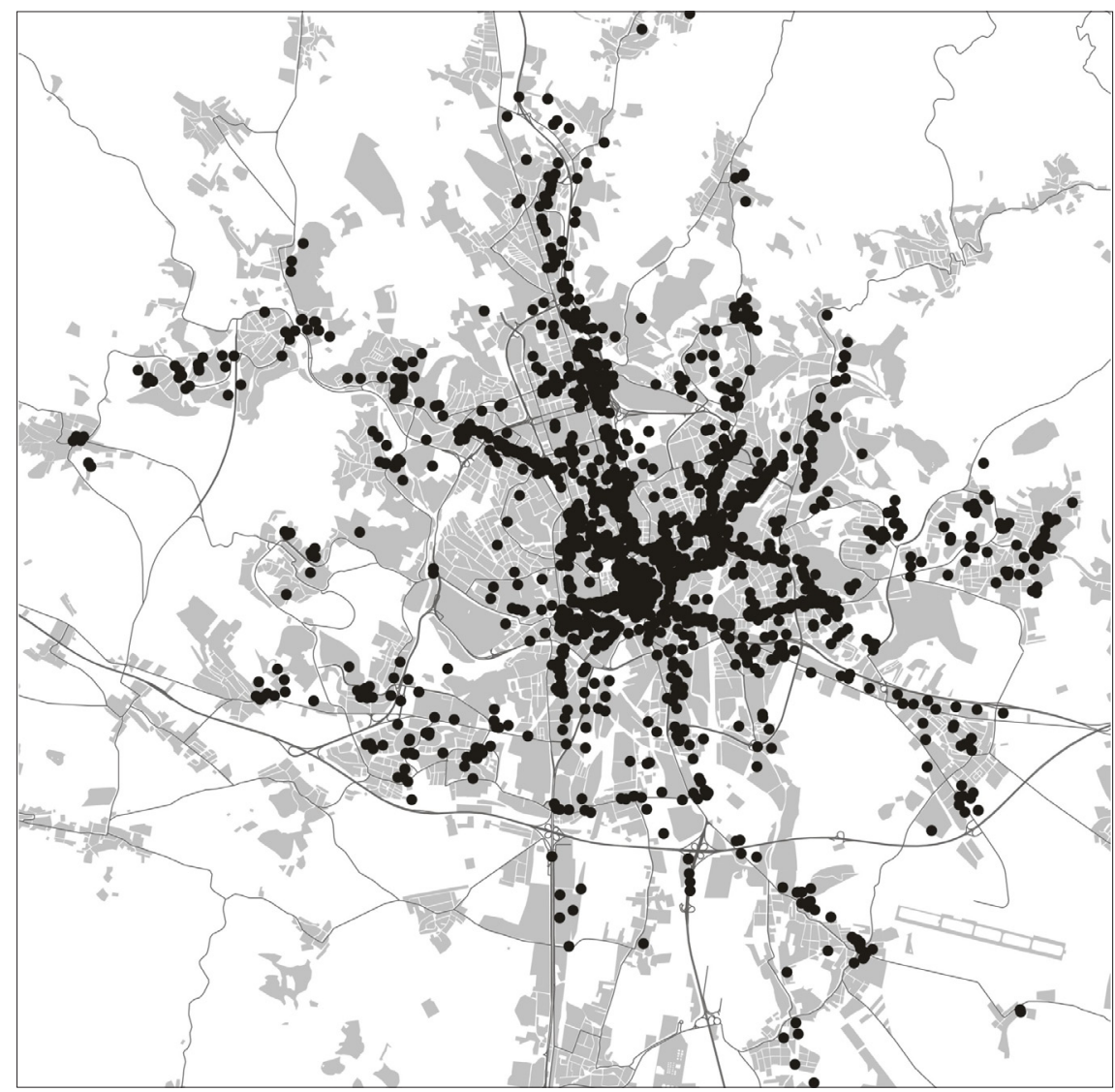

Fig. 6: Day chronotope of Brno in 2013 (12:00-12:59)

Source: authors' analysis 
of shop assistants or shopkeepers. If so, the institutional pacemaker of working hours is directly transferred this way into urban retail temporalities.

The second round of closures takes place at 6 p.m., after which only one third of stores in the city stay open. This is actually a sharp decrease, perhaps remotely resembling retailing temporality under socialism - as in those times, 18 o'clock was the typical closing hour imposed by the regulated central-command economy. With no research data, we can only speculate on possible inertias of retail temporalities being carried on to the unregulated postsocialist urban context of the contemporary Czech city. In any case, this evening time denotes a definitive break with the period of ubiquitous retail. The chronotopic retail map starts to be more fragmented and the question of "Where to shop?" becomes more closely linked to "What time is it?". As for the size and assortment structure of the open shops, they reflect the logic of flows of people in the city. For many, this is the time to make their daily shopping on their way home. Such a spatiotemporal constellation of customers favours larger supermarkets and hypermarkets located nearby the residential areas and transport lines, while the small specialised shops are likely to close. The average size of the open shops thus increases when compared with the time before 6 p.m., and the grocery assortment becomes relatively over-represented.

In the period from 7 to 10 p.m., the process of transition to the night-retail chronotope comes to its final stage. The number of working shops decreases gradually and the size structure of the retail units becomes more polarised as the stratum of middle-sized shops fades away. The large shops are represented by an assortment mix of businesses run under the umbrella of large shopping malls, which stay as a kind of temporal island amidst a pervading retail desert. Furthermore, there are also retail chain supermarkets carrying on the role of late evening retail points operating at the scale of residential neighbourhoods. They usually close between 8 and 10 p.m. The late evening opens the space also to small businesses with specific temporal strategies aimed at minor groups of late customers. Stores selling alcoholic beverages and cigarettes, as well as small groceries offering a narrow range of foodstuffs, are the typical representatives in bringing the city retail back into its nocturnal phase. At about 11 p.m., the working-day rhythm of retailing draws to a close and the night-time chronotope comes into its own right.

\section{Conclusions}

The authors do not see the city as a static product of past processes. Instead, the city is conceptualised here as a dynamic continuing process, as an entity being always in flux. The processional dynamism of the city environment, as presented here, is not linear in its nature. It is conceptualised as an ensemble of rhythmically repeating stages, with each stage enclosing a specific configuration of city functioning. The delimitation of these stages represents the main result of the underlying analytical work. The chronotopic approach introduces a temporal categorisation, dividing the 24-hour day into differently timed sections. Time can be partitioned into the years rhythmised by the cycle of particular seasons, into the weeks timed by the alternation of working and non-working days, or into the days which rhythm refers to in the schedule of work or school. Time can be divided into even more subtle units, however, but still internally cohesive fractions within the temporal scale of the 24-hour day.

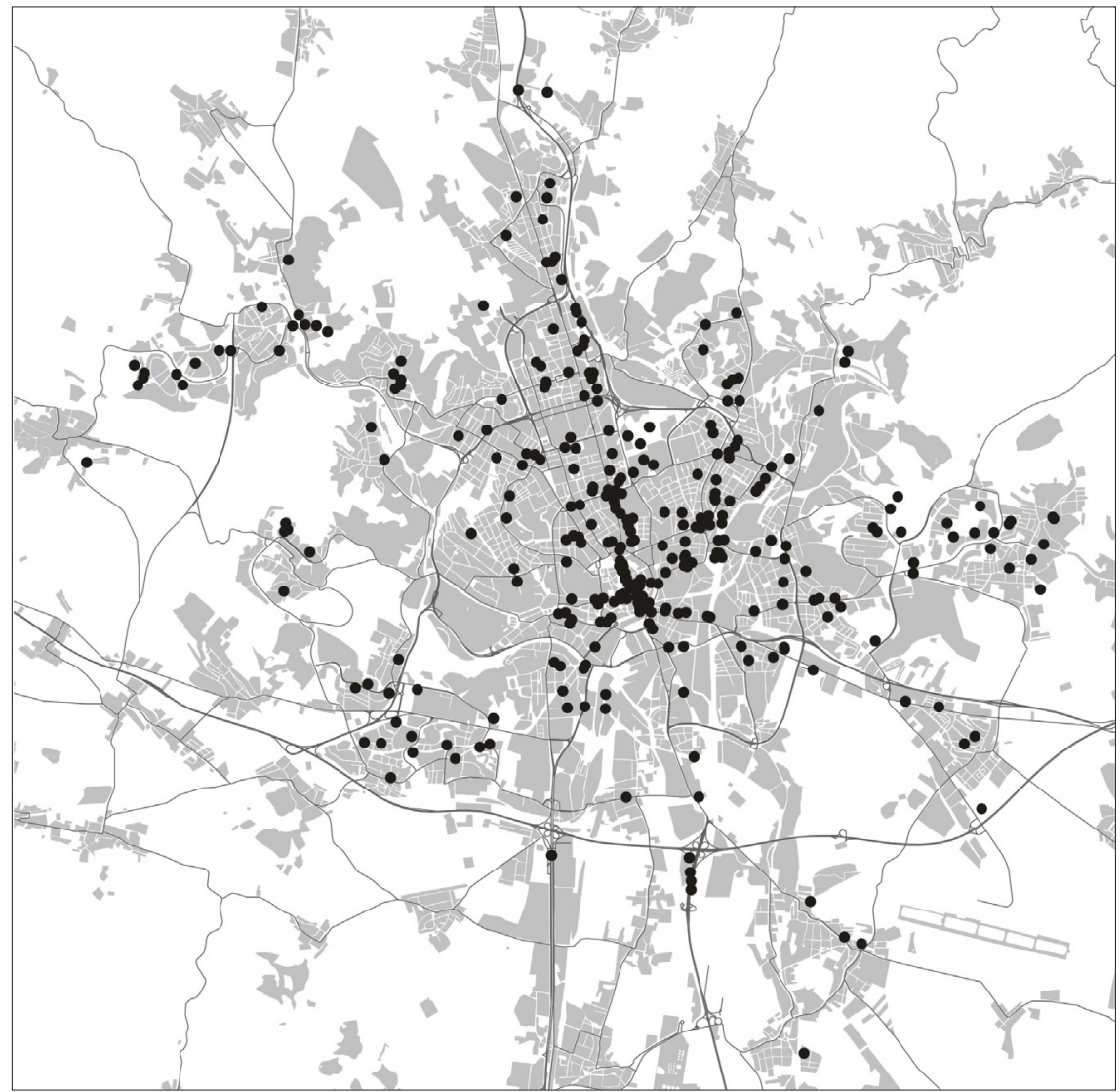

Fig. 7: Evening chronotope of Brno in 2013 (19:00-19:59)

Source: authors' analysis 


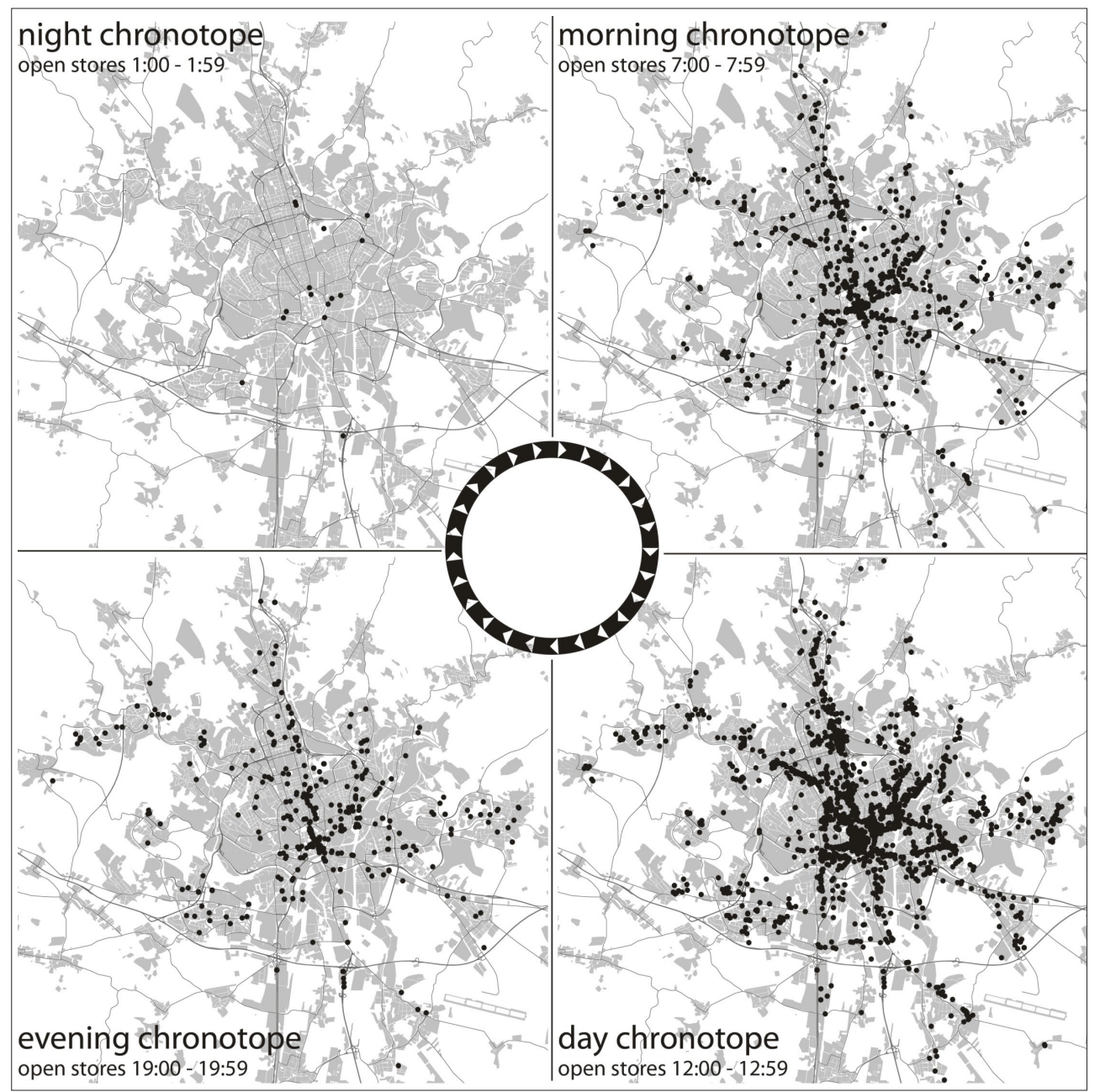

Fig. 8: Time-space description of Brno in 2013 as defined by the four chronotopes Source: authors' analysis

This paper presents one example of an alternative division of the day: summarised as Figure 8. Based on the temporal strategies of retailers, four distinct time-space configurations have been delimited - chronotopes of the night, morning, day and evening. These four chronotopes are not linked to the astronomical structuring of the 24-hour day - rather, they are social constructs. While the beginnings and the ends of the astronomical day change over the course of the year, the temporal co-ordinates of retail opening hours remain relatively stable. The retail stores open each morning of the weekday typically between 8 and 9 a.m. and close between 6 and 7 p.m., no matter whether there is daylight or evening dark. There is a certain clash between particular conceptions of time - the rhythmically repeating biological need for sleep (human biological time) interferes with linearly flowing time, which is so essential for the organisation of modern urban society (the machine time of industry and bureaucracy). Daylight or darkness are not the meaningful factors shaping the 24-hour day in the present city: it is structured under different, socially-based rhythms, with the rhythms of retail as the prominent ones. There are no astronomical or biological markers, like dawn or the songbirds separating the chronotope of the morning from the chronotope of the night. There are instead significant social markers represented by the opening times of various urban services.

Analogically, the start of the spring in the city does not coincide with snow-melting and the germination of plants. It is linked to the start of the new seasonal offers of the retail chains (Jauhiainen and Mönkkönen, 2005; Jauhiainen, 2007). The concept of the city as a cyclical process repeated in daily rhythms is emphasised here. The city-as-process is described by a sequence of relatively stable spatial-temporal stages stemming from the specific temporal strategies of retail stores. More generally, the paper offers an example of the ways in which the specific daily rhythmicity of the city gets structured.

On a more general theoretical level, this paper can be seen as a contribution to a critical re-conceptualisation of urban time. The classical studies often separated social and urban time as they understand urban time usually as linear, divided into formalised basic units such as a 24-hour working day (Melucci, 1996; Hoffmann and Lapeyre, 1995; Hoffmann, 1997; Bonfiglioli, 1997; Mareggi, 2002; Stavrides, 2012, 2013; Pasqui, 2016). In this contribution, however, we have a different conceptualisation of urban time - cyclical urban time, which consists of rhythmically repeating periods that are shorter than a day. In the case of Brno, there are four time-specific periods, four chronotopes that emerged not from astronomically- or institutionally-constituted categories of night, morning, day or evening, but from particular the spatiotemporal strategies of urban retailers.

\section{Acknowledgement}

This work was supported by the Czech Science Foundation [grant number 17-02827S]: Mapování každodennosti: reprezentace prostorů rutiny. 


\section{References:}

ADAM, B. (1994): Time and social theory. Cambridge, Polity Press.

ADAM, B. (1995): Timewatch: the social analysis of time. Cambridge, Polity Press.

ADAM, B. (2004): Time. Cambridge, Polity Press.

ASCHER, F. (1997): Du vivre en juste à temps au chronourbanisme. Les Annales de la recherche urbaine, 77(1): 112-122.

ASCHER, F. (2001): Les nouveaux principes de l'urbanisme. La fin des villes n'est pas à l'ordre du jour. Éditions de l'Aube.

ASCHER, F. (2008): Les nouveaux compromis urbains. Lexique de la ville plurielle. Editions de l'Aube.

BAKHTIN, M. (1980): Román jako dialog. Praha, Odeon.

BAKHTIN, M. (1984): Problems of Dostoevsky's Poetics. Minneapolis, University of Minnesota Press.

BAKHTIN, M. (1986): Speech Genres and Other Late Essays. Austin, University of Texas Press.

BACHTIN, M. (2002): Forms of Time and of the Chronotope in the Novel: Notes toward a Historical Poetics. In: Richardson, B. [ed.]: Narrative Dynamics: Essays on Time, Plot, Closure, and Frames (pp. 15-24). Columbus, Ohio State University Press.

BAUDRILLARD, J. (1973): The Mirror of Production. St Louis, Telos Press.

BONFIGLIOLI, S. (1997): Urban time policies in Italy: an overview of time-oriented research. Transfer: European Review of Labour and Research, 3(4): 700-722.

BOULIN, J. Y., MÜCKENBERGER, U. (2005): Is the societal dialogue at the local level the future of social dialogue? Transfer: European Review of Labour and Research, 11(3): 439-448.

BROMLEY, R., TALLON, A., THOMAS, C. (2003) Disaggregating the space-time layers of city-centre activities and their users. Environment and Planning A, 35(10): 1831-1851.

BYRNE, D. (2002): Industrial culture in a post-industrial world: The case of the North East of England. City, 6(3): 279-289.

CASTELLS, M. (1977): The Urban Question: A Marxist Approach. London, Edward Arnold Publishers.

CRANG, M. (2001): Rhythms of the city: Temporalised space and motion. In: May, J., Thrift, N. [eds.]: TimeSpace: Geographies of Temporality (pp. 187-207). London, Routledge.

CRANG, M. (2005): Time: Space. In: Cloke, P., Johnston R. [eds.]: Spaces of Geographical Thought: Deconstructing Human Geography's Binaries (pp. 199-220). London, Sage.

CREWE, L. (2000): Geographies of retailing and consumption. Progress in Human Geography, 24(2): 275-290.

DE CERTEAU, M. (1984): The Practice of Everyday Life. Berkeley, University of California Press.

FERNANDES, J. R. (2011): Area Based Initiatives and Urban Dynamics: The Case of Porto City Centre. Urban Research \& Pratice, 4(3): 285-307.

FERNANDES, J. R., CHAMUSCA, P. (2014): Urban Policies, Planning and Retail Resilience. Cities, 36: 170-177.
FERNANDES， J. R., CHAMUSCA， P., FRAGO, L., GASNIER, A., KARRHOLM, M., PUJOL, C. (2015): Time Policies, Urban Policies and Planning. GOT - Geografia e Ordenamento do Território, Revista Electrónica, Centro de Estudos de Geografia e Ordenamento do Território, Universidade do Porto, 7: 129-157.

FOLCH-SERRA, M. (1990): Place, Voice, Space: Mikhail Bakhtin's Dialogical Landscape. Environment and Planning D: Society and Space, 8(3): 255-274.

GOODIN, R. E. (2010): Temporal Justice. Journal of Social Policy, 39(1): 1-16.

GWIAZDZINSKI, L. (2014): The Nocturnal Condition. CoLaboratorio's Managing Group. Night Manifesto. Seeking Citizenshup 24h., CoLaboratorio's Managing Group, 53-70.

GWIAZDZINSKI, L. (2015): The Urban Night: A Space Time for Innovation and Sustainable Development. Articulo Journal of Urban Research, 11.

HERRSCHEL, T. (1999): The changing meaning of place in post-socialist Eastern Europe: Commodification, perception and environment. The Geographical Journal, 165(2): 130-134.

HOFFMANN, R. (1997): Time in the City a New Action Field for Trade Unions. European Review of Labour and Research, 3(4): 775-785.

HOFFMANN, R., LAPEYRE, J. (1995): A time for working a time for living, Brussels, ETUI.

HOLLOWAY, J. KNEALE, J. (2000): Mikhail Bakhtin: Dialogics of space. In: Crang, M., Thrift, N. [eds.]: Thinking Space (pp. 71-88). London, Routledge.

IKEA CZECH REPUBLIC (2013): Press release [online]. IKEA website. [cit. 11.11.2015]. Available at: http:// www.ikea.com/cz/cs/about_ikea/newsitem/opening_ hours

INDERST, R., IRMEN, A. (2005): Shopping hours and price competition. European Economic Review, 49(5): 1105-1124.

JAUHIAINEN, J. (2007): Seasonality, Rhythms and PostPostmodern Everyday Urban Landscapes. In: Palang, H., Sooväli, H., Printsmann, A. [eds.]: Seasonal Landscapes (pp. 231-256). Dordrecht, Springer Link.

JAUHIAINEN, J., MÖNKKÖNEN, M. (2005): Seasonality: Nature, People's Preferences and Urban Planning in Oulunsalo, Finland. Landscape Research, 30(2): 273-281.

JAYNE, M. (2006): Cities and Consumption. London, Routledge.

KAUFMAN, C., LANE, P. (1994): Shopping 24 Hours a Day: A Consumer Need or a Losing Strategy? Journal of Shopping Center Research, 1(1): 81-159.

KÄRRHOLM, M. (2009): To the rhythm of shopping - on synchronisation in urban landscapes of consumption. Social \& Cultural Geography, 10(4): 421-440.

KÄRRHOLM, M. (2012): Retailising Space; Architecture, Retail and the territorialisation of Public Space. Farnham, Ashgate.

KLINKE, I. (2013): Chronopolitics: A conceptual matrix. Progress in Human Geography, 37(5): 673-690.

KOSFELD, M. (2002): Why shops close again: An evolutionary perspective on the deregulation. European Economic Review, 46(1): 51-72. 
LANOIE, P., TANGUAY, G., VALLÉE, L. (1994): ShortTerm Impact of Shopping-Hour Deregulation: Welfare Implications and Policy Analysis. Canadian Public Policy / Analyse de Politiques, 20(2): 177-188.

LEFEBVRE, H., ELDEN, S. (2004): Rhythmanalysis: Space, Time and Everyday Life. London, Continuum.

MALLET, S. (2014): The urban rhythms of neoliberalization. Justice Spatiale-Spatial Justice, 6: 1-19.

MAREGGI, M. (2002): Innovation in Urban Policy: The Experience of Italian Urban Time Policies. Planning Theory \& Practice, 3(2): 173-194.

MELBIN, M. (1978): Night as Frontier. American Sociological Review, 43(1): 3-22.

MELUCCI, A. (1996): Youth, Time and Social Movements. Young, 4(2): 3-14.

MULÍČEK, O., OSMAN, R. (2013): Průzkum maloobchodn sítě na území města Brna. Brno, Magistrát města Brna.

MULÍČEK, O., OSMAN, R., SEIDENGLANZ, D. (2015): Urban rhythms: a chronotopic approach to urban timespace. Time \& Society, 24(3): 304-325.

MULÍČEK, O., OSMAN, R., SEIDENGLANZ, D. (2016): Time-space rhythms of the city - The industrial and postindustrial Brno. Environment and Planning A, 48(1): 115-131.

MÜCKENBERGER, U. (2011): Local time policies in Europe. Time \& Society, 20(2): 241-273.
OSMAN, R., MULÍČEK, O. (2017): Urban chronopolis: Ensemble of rhythmized dislocated places. Geoforum, 85: 46-57.

PAOLUCCI, G. (2001): The City's Continuous Cycle of Consumption: Towards a New Definition of the Power Over Time? Antipode, 33(4): 647-659.

PASQUI, G. (2016): Populations and Rhythms in Contemporary Cities. In: Pucci, P., Colleoni, M. [eds.]: Understanding Mobilities for Designing Contemporary Cities (pp. 49-63). London, Springer International Publishing.

SAUNDERS, P. (1985): Space, the City and Urban Sociology. In: Gregory, D., Urry, J. [eds.]: Social Relations and Spatial Structures (pp. 67-89). London, Macmillan.

SCHWANEN, T., VAN AALST, I., BRANDS, J., TIMAN, T. (2012): Rhythms of the night: spatiotemporal inequalities in the night-time economy. Environment and Planning A, 44(9): 2064-2085.

STAVRIDES, S. (2012): Squares in movement. South Atlantic Quarterly, 111(3): 585-596.

STAVRIDES, S. (2013): Contested urban rhythms: from the industrial city to the post-industrial urban archipelago. The Sociological Review, 61(S1): 34-50.

STRAW, W. (2015): Chrono-Urbanism and Single-Night Narratives in Film. Film Studies, 12(1): 46-56.

WENZEL, T. (2011): Deregulation of Shopping Hours: The Impact on Independent Retailers and Chain Stores. The Scandinavian Journal of Economics, 113(1): 145-166.

\section{Please cite this article as:}

MULÍČEK, O., OSMAN, R. (2018): Rhythm of urban retail landscapes: Shopping hours and the urban chronotopes. Moravian Geographical Reports, 26(1): 2-13. Doi: 10.2478/mgr-2018-0001. 